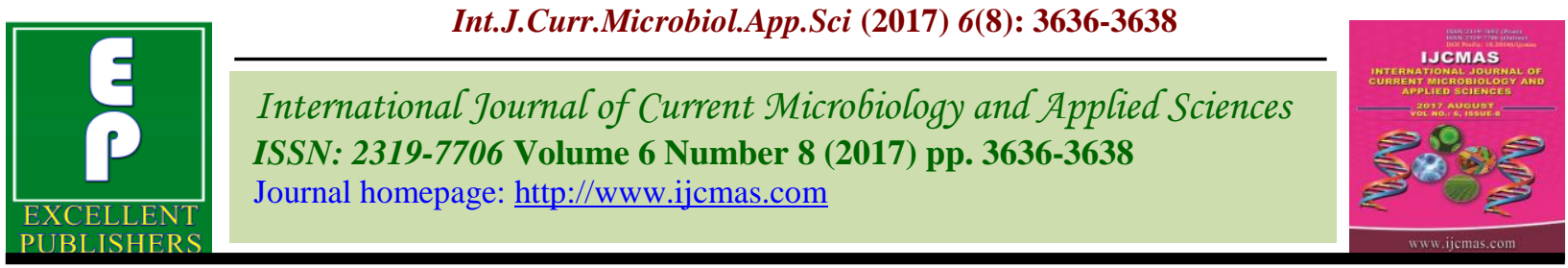

Original Research Article

https://doi.org/10.20546/ijcmas.2017.608.438

\title{
Studies on Effect of Organic Manuring in Onion cv. Akola Safed
}

\author{
Harshada P. Gite, P.K. Nagre and S.V. Khambalkar* \\ Department of Horticulture, Dr. Panjabrao Deshmukh Krishi Vidyapeeth, Akola, India \\ *Corresponding author
}

\section{A B S T R A C T}

\begin{tabular}{|l|}
\hline Ke y w or d s \\
Onion, Randomized \\
block design \\
(RBD), NPK, PSB.
\end{tabular}

An experiment "Studies on organic manuring in onion cv. Akola safed" was conducted during rabi season of 2013-14 at main garden, Department of Horticulture, Dr. Panjabrao Deshmukh Krishi Vidyapeeth, Akola to study the effect of different organic manures and bio-fertilizers for better growth, yield and quality of onion. The experiment was laid out in randomized block design with spacing $15 \times 10 \mathrm{~cm}$ and treatments comprised of one inorganic fertilizer (NPK- 100:50:50kg/ha) and three organics (FYM, Vermicompost, Neemcake) were used with bio-fertilizers like Azotobactor and PSB alone and in combination with one control. The result of present experiment revealed that the treatment of inorganic fertilizer i.e (100:50:50 NPK kg/ha) was found to be proved most beneficial for growing the growth of onion cv. Akola safed, which gave yield maximum up to 258.85 q/ha.

\section{Introduction}

Onion (Allium cepa.L) is one of the important vegetable in India. It is widely consumed throughout the year as salad and culinary purpose for flavoring of dishes and as spices in pickles, sauce and vegetables. In India the estimated area of onion is 10.515 hectare with production 16.813 MT/ha and Maharashtra occupied $28 \%$ share in onion production. Which shared the area of 2.60 lakh hectare, production 4.66 lakh MT and productivity of 17.9 MT/ha. Among many constrains for low productivity in onion, imbalanced nutrition is the main limiting factor. The Organics are not only the sources of crop nutrition but also improves the soil fertility which is very important for sustainability in higher yields of crop as well as soil health. Organic crop production is not only a holistic approach of production system but also gives quality 'organic food' and helps to restore soil fertility on long term basis. It is relatively independent production system compared to conventional agriculture. The organic manures like farm yard manures, vermicompost increases the mineral nutrients, growth hormones, vitamins and improving other physical characters in soil (Ismail, 1995).

The lowest population of bio-fertilizers containing bacteria in soil with chemical fertilizers may be due to the absence of organic matter in soil and no stimulative effect to increase the bacterial population. Hence there is a need to find out suitable organic manure in combination with biofertilizers (Azotobactor +PSB) for improving yield and quality of onion. The Bio-fertilizers, in combination with organic manures, play an important role in agriculture, responsible for 
increasing the organic manures in their available forms to plants and also increases yield by up to $20 \%$.

\section{Materials and Methods}

A field experiment was conducted in randomized block design (RBD) at Main garden, Department of Horticulture, Dr. Panjabrao Deshmukh Krishi Vidyapeeth, Akola, during January to May. The treatments were arranged in randomized block design with three replications; and each replication was divided in to eleven plots. The seeds of onion were sown and 60 days old seedlings were transplanted at a spacing of $15 \mathrm{~cm}$ (row to row) and $10 \mathrm{~cm}$ (plant to plant). The seedlings were inoculated with Azotobactor alone, PSB alone and in combination with Azo+ PSB by soaking them in slurry for about half an hour. There were eleven treatments comprising organic manures (FYM @ 10t/ha, Vermicompost @ 6.6t/ha and Neemcake @ 7t/ha), bio-fertilizers (Azotobactor and Phosphate solublising bacteria, PSB@ 5 Kg/ha and NPK (100:50:50 $\mathrm{Kg} / \mathrm{ha}$ ). These treatments: $\mathrm{T}_{1}$ (RDF (100:50:50 kg of NPK/ha), T2 (FYM @ 10 t/ha), $\mathrm{T}_{3}$ (Vermicompost @ 6.6 t/ha), $\mathrm{T}_{4}$ (Neem cake@7t/ha), T5 (Azotobacter @ 5 $\mathrm{kg} / \mathrm{ha}$ ), T 6 (Phosphate solublising bacteria@ $5 \mathrm{~kg} / \mathrm{ha}), \mathrm{T}_{7}$ (Azotobacter + PSB @ $5 \mathrm{~kg} / \mathrm{ha}$ each), T8 (FYM @ 10 t/ha + Azotobacter + PSB @ 5 kg/ha each), T9 (Vermicompost @ 6.6 t/ha + Azotobacter + PSB @ 5 kg/ha each), $\mathrm{T}_{10}$ (Neemcake@ 7 t/ha + Azotobacter + PSB@ 5 kg/ha each), $\mathrm{T}_{11}$ (Control). Five plants from each plot were randomly selected for recording plant height $(\mathrm{cm})$, Number of leaves, Leaf area $\left(\mathrm{cm}^{2}\right)$, Diameter of bulb (cm), Average weight of bulb (gm) and Total soluble solids (TSS, ${ }^{\circ}$ Brix).

\section{Results and Discussion}

The plant height, number of leaves and leaf area per plant of onion increased at age of plant up to 90 DAT (Table 1). Due to application of NPK @ 100:50:50Kg/ha resulted in significantly higher growth characters and yield of onion bulbs followed by the treatment of Vermicompost @ 6.6t/ha+ Azotobactor @5kg/ha+ PSB @ 5Kg/haand FYM @10t/ha+ Azotobactor @ 5kg/ha+ PSB @ $5 \mathrm{Kg} / \mathrm{ha}$ respectively.

Table.1 Growth, yield and yield-components of onion as influenced by organic manuring in onion

\begin{tabular}{|c|c|c|c|c|c|c|}
\hline Treatments & $\begin{array}{l}\text { Plant Height } \\
\text { (90DAT) } \\
\text { (cm) }\end{array}$ & $\begin{array}{l}\text { Number } \\
\text { of leaves } \\
\text { (90DAT) }\end{array}$ & $\begin{array}{c}\text { Leaf area } \\
(90 D A T) \\
\left(\mathrm{cm}^{2}\right)\end{array}$ & $\begin{array}{l}\text { Diameter } \\
\text { of bulb } \\
\text { (cm) }\end{array}$ & $\begin{array}{c}\text { Average } \\
\text { weight of } \\
\text { bulb (gm) }\end{array}$ & $\begin{array}{l}\text { Bulb } \\
\text { yield } \\
\text { (q/ha) }\end{array}$ \\
\hline $\mathrm{T}_{1}-\mathrm{RDF}(100: 50: 50 \mathrm{~kg}$ of NPK/ha) & 78.04 & 8.89 & 380.50 & 6.15 & 65.10 & 258.85 \\
\hline $\mathrm{T}_{2}$-FYM @ 10t/ha & 69.68 & 8.30 & 355.45 & 5.80 & 53.20 & 210.49 \\
\hline T3-Vermicompost @ 6.6 t/ha & 73.06 & 8.48 & 364.30 & 6.05 & 62.15 & 231.48 \\
\hline $\mathrm{T}_{4}$-Neem cake @ 7t/ha & 60.82 & 6.66 & 351.28 & 5.00 & 48.14 & 179.62 \\
\hline $\mathrm{T}_{5}$-Azotobacter@5 kg/ha & 60.02 & 6.41 & 302.25 & 4.51 & 40.03 & 155.55 \\
\hline $\begin{array}{l}\mathrm{T}_{6} \text {-Phosphorus solublising bacteria @ } 5 \\
\mathrm{~kg} / \mathrm{ha}\end{array}$ & 65.38 & 6.51 & 308.32 & 4.58 & 40.15 & 149.99 \\
\hline $\mathrm{T}_{7}$-Azotobacter $+P S B @ 5 \mathrm{~kg} / \mathrm{ha}$ each & 67.40 & 6.71 & 315.45 & 4.66 & 46.66 & 159.26 \\
\hline $\begin{array}{l}\text { T8-FYM @ } 10 \text { t/ha + Azotobacter + PSB @ } \\
5 \mathrm{~kg} / \mathrm{ha} \text { each }\end{array}$ & 72.29 & 8.62 & 365.55 & 6.03 & 61.32 & 223.45 \\
\hline $\begin{array}{l}\mathrm{T}_{9} \text {-Vermicompost @ } 6.6 \mathrm{t} / \mathrm{ha}+\text { Azotobacter } \\
+ \text { PSB @ } 5 \mathrm{~kg} / \mathrm{ha} \text { each }\end{array}$ & 76.48 & 8.80 & 372.38 & 6.10 & 64.07 & 251.11 \\
\hline $\begin{array}{l}\mathrm{T}_{10} \text {-Neemcake @ } 7 \mathrm{t} / \mathrm{ha}+\text { Azotobacter + } \\
\text { PSB @ } 5 \mathrm{~kg} / \mathrm{ha} \text { each }\end{array}$ & 70.90 & 7.87 & 360.38 & 5.25 & 52.29 & 200.63 \\
\hline $\mathrm{T}_{11}$-Control & 58.05 & 6.15 & 303.30 & 4.25 & 38.14 & 140.74 \\
\hline
\end{tabular}


In conclusion among all treatments, the recommended dose of NPK i.e $\mathrm{T}_{1}$ (100:50:50Kg/ha) application proved the most beneficial for growing onion cv. Akola safed in this region maximum up to $258.85 \mathrm{q} / \mathrm{ha}$ onion bulb. However, the second best treatment was Vermicompost@ 6.6t/ha+ Azotobactor @ 5kg/ha+ PSB @ 5Kg/hawhich yielded $251.11 \mathrm{q} /$ ha followed by FYM and Neemcake in combination with bio-fertilizer (Azotobactor + PSB @ $5 \mathrm{Kg} / \mathrm{ha}$ each).

\section{References}

Anonymous. 2013a. Effect of soil application of various organic manures on growth, yield, quality and storage life of onion and garlic", Directorate of onion and garlic research, Rajgurunagar, Pune, Annual Report 2012-13, pp. 35-36.

Jayathilake P.K.S, Reddy I.P and Srihari D (2002). Effect of nutrient management on growth, yield and yield attributes of Rabi onion (A.cepa L.). Vegetable science29(2): 184-185.

Panse, V.G. and Sukhatme, P.V. (1967) "Statistical methods for Agricultural Workers", ICAR, New Delhi.

Yeptho A.K, Singh A.K, Kanaujia S.P and Singh V.B (2012). Quality production of Kharip onion (A.cepa. L) in response to bio-fertilizers inoculated organic manures. Indian J. of Agril. Sci.83(3): 236-240.

\section{How to cite this article:}

Harshada P. Gite, P.K. Nagre and Khambalkar, S.V. 2017. Studies on Effect of Organic Manuring in Onion cv. Akola Safed. Int.J.Curr.Microbiol.App.Sci. 6(8): 3636-3638. doi: https://doi.org/10.20546/ijcmas.2017.608.438 